\title{
Islet autoantibody markers in IDDM: risk assessment strategies yielding high sensitivity
}

\author{
E. Bonifacio $^{1}$, S. Genovese ${ }^{1}$, S. Braghi ${ }^{1}$, E. Bazzigaluppi ${ }^{1}$, V. Lampasona ${ }^{1}$, P. J. Bingley ${ }^{2}$, L. Rogge ${ }^{3}$, M. R. Pastore ${ }^{1}$, \\ E. Bognetti ${ }^{1}$, G. F. Bottazzo ${ }^{4}$, E. A.M. Gale ${ }^{2}$, E. Bosi ${ }^{1}$ \\ ${ }^{1}$ Istituto Scientifico San Raffaele, University of Milan, Milan, Italy \\ ${ }^{2}$ Department of Diabetes and Metabolism, St Bartholomew's Hospital Medical College, London, UK \\ ${ }^{3}$ Roche Milano Ricerche, Milan, Italy \\ ${ }^{4}$ Department of Immunology, London Hospital Medical College, London, UK
}

Summary Identification of islet autoantigens offers the possibility that antibody tests other than islet cell antibodies may be used for assessing risk of insulindependent diabetes mellitus (IDDM). The aim of this study was to determine the combination of islet autoantibody markers that could identify most future cases of IDDM. Islet cell antibodies, antibodies to glutamic acid decarboxylase (GAD) $)_{65}, 37,000$ / $40,000 \mathrm{M}_{\mathrm{r}}$ islet tryptic fragments, carboxypeptidase$\mathrm{H}$, and islet cell autoantigen (ICA)69 were measured in sera from 100 newly-diagnosed IDDM patients, 27 individuals prior to onset of IDDM, and 83 control subjects. Islet cell antibodies were detected in $88 \%$ of IDDM patients and $81 \%$ with pre-IDDM, GAD 65 antibodies in $70 \%$ of IDDM patients and $89 \%$ with pre-IDDM, and antibodies to $37,000 / 40,000 \mathrm{M}_{\mathrm{r}}$ islet tryptic fragments in $54 \%$ of IDDM patients and in $48 \%$ with pre-IDDM. The latter were found only in conjunction with islet cell antibodies and were more frequent in young onset cases. All 20 IDDM patients and the 3 pre-IDDM subjects who had islet cell anti- bodies without $\mathrm{GAD}_{65}$ antibodies had antibodies to $37,000 / 40,000 \mathrm{M}_{\mathrm{r}}$ islet tryptic fragments, and all but one had disease onset before age 15 years. No sera strongly immunoprecipitated in vitro translated ICA69 or carboxypeptidase-H; $4 \%$ of patients had anti-ICA69 and $11 \%$ anti-carboxypeptidase-H levels above those of the control subjects. The findings suggest that none of the single antibody specificities are as sensitive as islet cell antibodies, but that a combination of $\mathrm{GAD}_{65}$ antibodies and antibodies to $37,000 / 40,000 \mathrm{M}_{\mathrm{r}}$ islet tryptic fragments has the potential to identify more than $90 \%$ of future cases of IDDM. Such a strategy could eventually replace islet cell antibodies in population screening for IDDM risk assessment. [Diabetologia (1995) 38: 816-822]

Key words Islet cell antibodies, glutamic acid decarboxylase $_{65}$ antibodies, islet autoantigens, insulin-dependent diabetes mellitus prediction, carboxypeptidase-H, ICA69.
Treatments that may delay or prevent the onset of insulin-dependent diabetes (IDDM) are already being tested in large-scale trials in family members of chil-

Received: 17 October 1994 and in revised form: 29 December 1994

Corresponding author: Dr. E. Bonifacio, Department of Medicine I, Istituto Scientifico San Raffaele, via Olgettina 60, I20132 Milan, Italy

Abbreviations: CL, Confidence limits; CPH, carboxypeptidase-H; GAD, glutamic acid decarboxylase; GADA, glutamic acid decarboxylase ${ }_{65}$ antibodies; IAA, insulin autoantibodies; ICA, islet cell antibodies; IDDM, insulin-dependent diabetes mellitus; JDF units, Juvenile Foundation Diabetes units. dren with the disease [1]. Although current risk assessment strategies are based on prospective family studies [2-4], only around $10 \%$ of patients have a first-degree family history of IDDM. If preventive therapies are to have a real impact on the frequency of disease, they will eventually have to be evaluated and applied in the population as a whole.

Islet cell antibodies (ICA) are the most widely used antibody marker in risk assessment [5]. Over $80 \%$ of first-degree relatives who develop IDDM have detectable ICA, and unaffected relatives with ICA are at greatly increased risk of developing the disease [2-4]. The technical limitation of ICA measurements is that they rely on semi-quantitative indi- 
rect immunofluorescent assays [6] which, despite much improvement [7], are difficult to standardize $[8,9]$. Antibodies to the islet autoantigen glutamic acid decarboxylase (GAD) are also detected prior to onset of IDDM [10-14]. The recent development of GAD antibody (GADA) assays [15, 16] which use small volumes of serum and detect antibodies in over $70 \%$ of IDDM patients, now offer the possibility to screen large sample numbers. Similar methods could potentially be applied to other proposed antibody markers [17] and it may ultimately be possible to develop a single assay measuring antibodies to several islet antigens, thus replacing ICA testing.

We have measured antibodies to GAD, 37,000/ $40,000 \mathrm{M}_{\mathrm{r}}$ islet tryptic fragments (anti-37 K) [18], carboxypeptidase-H (CPH) [19], and ICA69 [20], in 100 consecutive patients with newly-diagnosed IDDM, in 83 control subjects and in samples taken prior to onset of IDDM from 27 individuals in the BartsWindsor [2] and Barts-Oxford family studies [13]. The aim of the study was to select the best combination of antibody markers for use in a screening test for IDDM risk assessment and to evaluate these in comparison with ICA.

\section{Subjects, materials and methods}

\section{Subjects}

Patients with IDDM. Serum samples were obtained at onset of disease from 100 consecutive patients with IDDM diagnosed at the San Raffaele Hospital, Milan, Italy, during 1990 and 1991. IDDM was defined on the basis of a clinical diagnosis. All patients started insulin at the time of diagnosis and remained insulin-dependent thereafter. Patients had a median age of 11 years (range 1 to 40 years). Sixty-nine were diagnosed before age 15 years, and 53 were male.

Pre-IDDM. Serum taken prior to diagnosis was available in 27 of the 29 family members who have developed IDDM whilst under follow-up in the Barts-Windsor [2] and Barts-Oxford family studies in the UK [13]. They were all included irrespective of ICA status. The first available serum sample from each individual was tested. Six parents and 21 siblings of the diabetic proband were studied. The median age at sample collection was 17 years (range 2 to 55 years) and at diagnosis of IDDM was 20 years (range 3 to 57 years). The median time to diagnosis was 2.7 years (range 0.2 to 8.1 years).

Control subjects. Samples were collected from 83 normal children and blood donors in the Milan area. They had a median age of 12 years (range 1 to 40 years), 37 were male.

\section{Recombinant autoantigens}

Poly-A RNA was isolated from 20,000 purified human islets using Dynabeads Oligo dT(25) (Dynal, Oslo, Norway) [21]. Reverse transcription of $3 \mu \mathrm{l}$ of the poly-A was performed using a mixture of random hexamers (Perkin Elmer Cetus, Norwalk, Conn., USA) to obtain cDNA [22]. The full length coding sequences of $\mathrm{GAD}_{65}$ and ICA69 were obtained after polymerase chain reaction amplification [23] of cDNA. The amplified products were ligated into the plasmid vector pCRII (Invitrogen, San Diego, Calif., USA), and then subcloned into the ECoR1 $\left(\mathrm{GAD}_{65}\right)$ or BamH1 (ICA69) cloning sites of the pGEM 3 vector (Promega, Madison, Wis., USA) under the control of the SP6 promotor for in vitro transcription and expression [24]. Recombinant rat CPH cDNA, cloned into the pSP64 vector (Promega) under the control of the SP6 promotor, was kindly provided by Dr. J. Hutton, Addenbrooke's Hospital, Cambridge, UK.

Radiolabelled recombinant proteins were obtained from in vitro coupled transcription and translation of $1 \mu \mathrm{g}$ of the appropriate plasmid by SP6 RNA polymerase and rabbit reticulocyte lysate (Promega) in the presence of $40 \mu \mathrm{Ci}{ }^{35} \mathrm{~S}$-methionine (Amersham International, Amersham Bucks., UK). Unincorporated label was removed by gel chromatography on a NAP 5 column (Pharmacia, Uppsala, Sweden).

\section{Autoantibody measurements}

$G A D A$. Antibodies to in vitro translated $\mathrm{GAD}_{65}$ were measured using a method similar to that previously described [16]. A total of $15,000 \mathrm{cpm}$ of labelled $\mathrm{GAD}_{65}$ protein diluted in

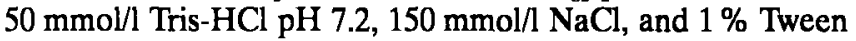
20 (TBST) was added to $2 \mu \mathrm{l}$ of serum to a final volume of $50 \mu \mathrm{l}$ in 96-deep well microtitre plates and incubated overnight on ice. Immunocomplexes were isolated on $1 \mathrm{mg}$ protein A Sepharose (Pharmacia), pre-swelled and resuspended in $50 \mu \mathrm{l}$ of TBST, followed by incubation for $1 \mathrm{~h}$ at $4^{\circ} \mathrm{C}$ with shaking. The immunocomplexes bound to protein $A$ were washed once with $750 \mu \mathrm{l}$ of cold TBST and transferred to a 96-well filtration system (Millipore, Bedford, Mass., USA) with a 0.45 $\mu \mathrm{m}$ filter at the bottom of the wells. The unit was placed on a vacuum device and after 10 washes, each of $150 \mu$ l of TBST, the bottom of each well was punched into a scintillation vial containing $2.5 \mathrm{ml}$ of scintillation fluid (Ultimagold, Packard, Groningen, The Netherlands), and cpm measured in a scintillation counter (Kontron Instruments, Montigny le Bretonnieux, France). All samples were tested in duplicate. Results are expressed as mean $\mathrm{cpm}$. The interassay coefficient of variation on 10 assays was less than $15 \%$ for control samples with mean cpms of 300 and 600 . This assay detected none of 32 control samples and 32 of 39 (82 \%) IDDM samples in the 2nd International GAD antibody workshop.

Anti-carboxypeptidase- $H$ and anti-ICA69. Antibodies to in vitro translated CPH and ICA69 were measured as previously described for anti-ICA69 [24]. A total of $17,000 \mathrm{cpm}$ of labelled protein diluted in TBST was added to $4 \mu \mathrm{l}$ of serum in a final volume of $50 \mu \mathrm{l}$ in 96-deep-well microtitre plates and incubated overnight on ice. Immunocomplexes were isolated on $2 \mathrm{mg}$ protein A Sepharose (Pharmacia), pre-swelled and resuspended in $50 \mu \mathrm{l}$ of TBST, followed by incubation for $1 \mathrm{~h}$ at $4^{\circ} \mathrm{C}$ with shaking. For anti-CPH, immunocomplexes bound to protein $\mathrm{A}$ were washed eight times, each with $750 \mu \mathrm{l}$ of cold TBST, transferred to scintillation vials containing $2.5 \mathrm{ml}$ of scintillation fluid, and the $\mathrm{cpm}$ measured. For anti-ICA69, immunocomplexes bound to protein $A$ were washed twice, each with $750 \mu \mathrm{l}$ of cold TBST and transferred to a 96-well filtration system, washed and counted as for GADA. Rabbit polyclonal anti-CPH provided by Dr. J. Hutton and a rabbit polyclonal antiserum raised against purified recombinant ICA69 protein (Primm, Milan, Italy) strongly immunoprecipitated the in vitro translated proteins (Fig.1). 


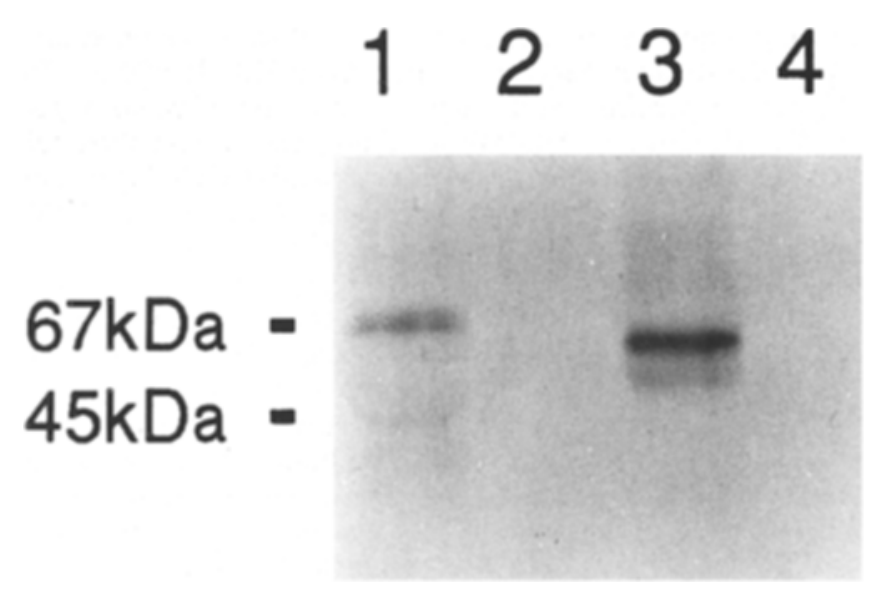

Fig.1. Immunoprecipitation of in vitro translated, ICA69 (lanes 1 and 2) and CPH (lanes 3 and 4). ${ }^{35} \mathrm{~S}$ methionine labelled protein was immunoprecipitated with $0.2 \mu \mathrm{l}$ rabbit antiICA69 (lane 1), $0.2 \mu \mathrm{l}$ rabbit anti-CPH (lane 3), and $2 \mu \mathrm{l}$ preimmune rabbit sera (lanes 2 and 4 ), and run on $10 \%$ polyacrylamide gel electrophoresis under denaturing conditions

Dilutions of these antisera were used as controls in each assay.

Anti-37 K. Rat insulinoma cell line (RIN 5AH) was maintained in tissue culture in RPMI 1640 medium containing $10 \%$ fetal bovine serum (Sigma, St. Louis, Mo., USA). Subconfluent RIN cells in a $162-\mathrm{cm}^{2}$ tissue culture flask (approximately $1 \times 10^{8}$ cells) were radiolabelled in methionine-free RPMI 1640 medium (Sigma) with $1 \mathrm{mCi}$ of $\left[{ }^{35} \mathrm{~S}\right]$ in vitro cell labelling mix (Promix - Amersham International) for $5 \mathrm{~h}$ at $37^{\circ} \mathrm{C}$; the cell pellet was then frozen at $-80^{\circ} \mathrm{C}$ until processed. For cell lysis, $400 \mu \mathrm{l}$ of $10 \mathrm{mmol} / \mathrm{l} \mathrm{Hepes}(\mathrm{pH} 7.4), 150 \mathrm{mmol} / 1 \mathrm{NaCl}, 0.1 \%$ (weight/volume) aprotinin, and $2 \%$ Triton X-114 were added to a pellet of radiolabelled insulinoma cells followed by $2 \mathrm{~h}$ incubation at $4^{\circ} \mathrm{C}$ with agitation. The homogenate was centrifuged at $10,000 \mathrm{~g}$ for $15 \mathrm{~min}$ at $4{ }^{\circ} \mathrm{C}$, and the supernatant collected and incubated at $30^{\circ} \mathrm{C}$ for phase separation. Triton X-114 detergent phase was precleared with $50 \mu 1$ of normal human serum for $18 \mathrm{~h}$ at $4^{\circ} \mathrm{C}$ followed by binding to $100 \mu \mathrm{l}$ of packed protein A Sepharose (Sigma) for $30 \mathrm{~min}$ at $4^{\circ} \mathrm{C}$. Aliquots of $20 \mu \mathrm{l}$ extract containing $4 \times 10^{6} \mathrm{cpm}$ of radiolabelled protein were incubated with $5 \mu \mathrm{l}$ of test serum for $5 \mathrm{~h}$ at $4^{\circ} \mathrm{C}$. Immune complexes were isolated on $20 \mu \mathrm{l}$ of packed protein A Sepha-

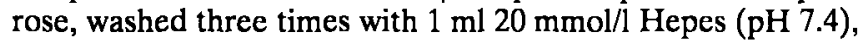
$500 \mathrm{mmol} / \mathrm{l} \mathrm{NaCl}$, and once with $1 \mathrm{ml}$ of water. They were then incubated with $50 \mu \mathrm{l}$ of $0.1 \mathrm{mg} / \mathrm{ml}$ trypsin in $10 \mathrm{mmol} / \mathrm{l}$ Hepes (pH 7.4), and $150 \mathrm{mmol} / \mathrm{l} \mathrm{NaCl}$ for $20 \mathrm{~min}$ at $4^{\circ} \mathrm{C}$, washed with $1 \mathrm{ml}$ of water before processing for SDS- $10 \%$ polyacrylamide gel electrophoresis and autoradiography. Serum samples were regarded as anti-37 $\mathrm{K}$ positive if $37 \mathrm{kDa}$ and/or $40 \mathrm{kDa}$ polypeptide bands were detected on the autoradiogram.

Islet cell antibodies (ICA). These were measured in undiluted sera by indirect immunofluorescence on 4- $\mu \mathrm{m}$ cryostat sections of blood group $\mathrm{O}$ human pancreas as previously described [2]. Positive samples were titrated to end point in doubling dilutions in $10 \mathrm{mmol} / \mathrm{l}$ phosphate-buffered saline $(\mathrm{pH}$ 7.2). Local (Milan) standard sera calibrated to 2.5, 5, 10, 20, 40 and 80 Juvenile Diabetes Foundation (JDF) units were included in each assay. End-point titres of test samples were converted to JDF units by comparison with a standard curve of $\log _{2}$ JDF units vs $\log _{2}$ of end-point titre of the standard sera. The threshold of ICA detection was 2 JDF units.

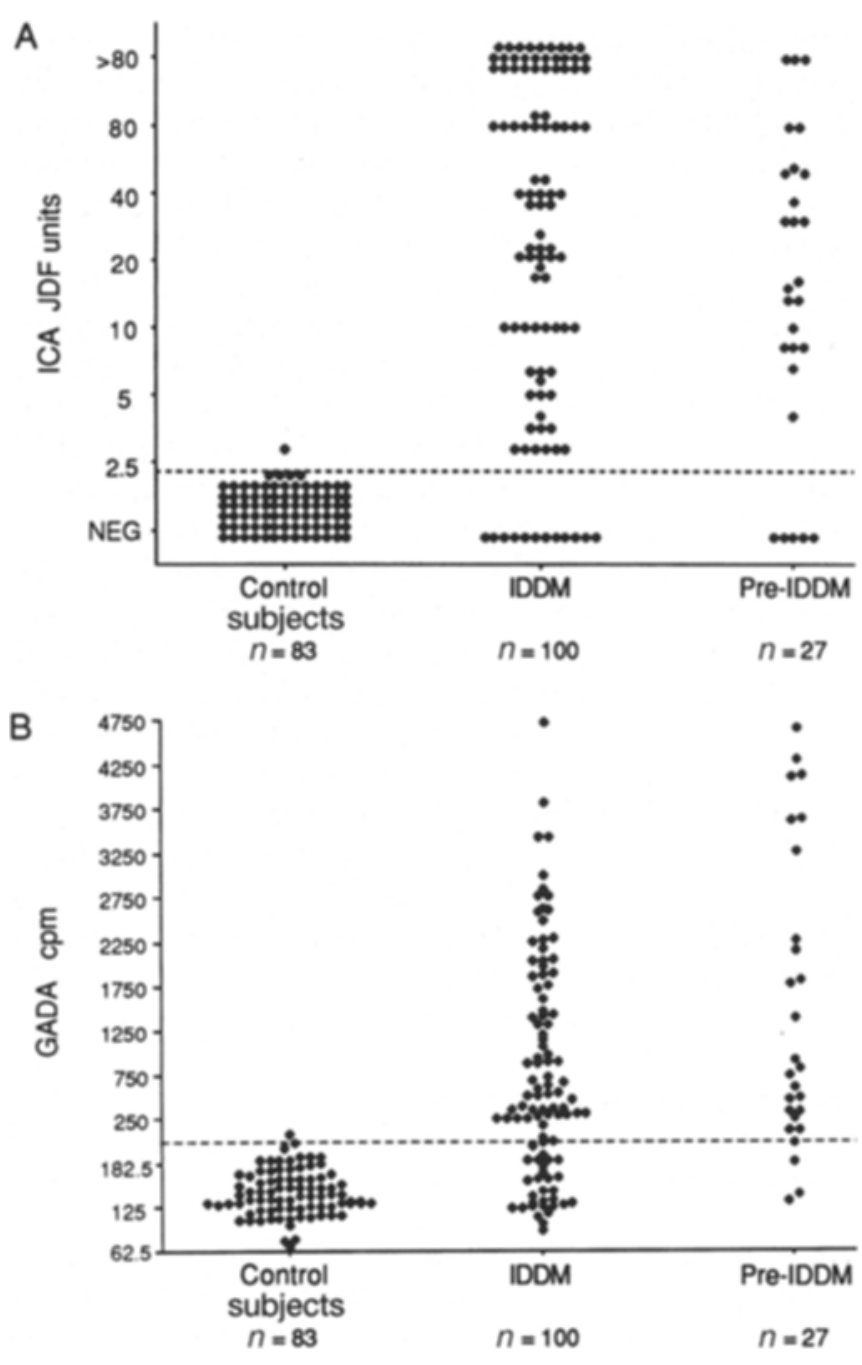

Fig. 2. (A) ICA and (B) GADA distribution in study groups. The upper first percentile of control subjects is shown by the broken lines

Insulin autoantibodies (IAA). These were measured on samples in which ICA were not detected using a radio-binding assay as previously described [25].

\section{Statistical analysis}

The threshold for positivity was selected as the upper first percentile of control results in each assay. All assays will have the same specificity ( $99 \%$ ) allowing comparison of sensitivities between them. All comparisons were made using the chi-square test with Yates' correction. $p$ values for comparisons between paediatric (onset $<15$ years) and older-onset cases were corrected for the number of categories $(n=5)$. Where appropriate, $95 \%$ confidence limits $(\mathrm{CL})$ are given.

\section{Results}

Insulin-dependent diabetes mellitus (IDDM). ICA were detected in 88 of 100 cases at onset of IDDM 
Table 1 Islet antibody prevalence

\begin{tabular}{llrrrrrl}
\hline Patient group & Age (years) & \multicolumn{1}{c}{$n$} & \multicolumn{1}{c}{ ICA } & GADA & Anti-37K & Anti-CPH & Anti-ICA69 \\
\hline IDDM & $\leq 15$ & 69 & $64(93 \%)$ & $45(65 \%)$ & $43(62 \%)$ & $10(13 \%)$ & $2(3 \%)$ \\
& $>15$ & 31 & $24(77 \%)$ & $25(81 \%)$ & $11(35 \%)^{\mathrm{a}}$ & $3(10 \%)$ & $0(0 \%)$ \\
Total & & 100 & 88 & 70 & 54 & 13 & 2 \\
Pre-IDDM & $\leq 15$ & 10 & $9(90 \%)$ & $8(80 \%)$ & $5(50 \%)$ & $1(10 \%)$ & $1(10 \%)$ \\
& $>15$ & 17 & $13(76 \%)$ & $16(94 \%)$ & $8(46 \%)$ & 0 & $2(12 \%)$ \\
Total & & 27 & $22(81 \%)$ & $24(89 \%)$ & $13(48 \%)$ & $1(4 \%)$ & $3(11 \%)$ \\
Control subjects & & 83 & $1(1 \%)$ & $1(1 \%)$ & $0(0 \%)$ & $1(1 \%)$ & $1(1 \%)$ \\
\hline
\end{tabular}

${ }^{\mathrm{a}} p<0.05 \mathrm{vs} \leq 15$ years

Table 2. Islet antibody combination

\begin{tabular}{|c|c|c|c|c|c|c|c|}
\hline \multirow[t]{2}{*}{ Patient group } & \multirow{2}{*}{$\begin{array}{l}\text { Age } \\
\text { (years) }\end{array}$} & \multirow[b]{2}{*}{$n$} & \multicolumn{5}{|c|}{ ICA/GADA/Anti-37K } \\
\hline & & & $+1+1+$ & $+/+1-$ & $+1-1+$ & $-1+1-$ & $-1-1-$ \\
\hline \multicolumn{8}{|l|}{$\overline{I D D M}$} \\
\hline & $\leq 15$ & 69 & $23(33 \%)$ & $21(30 \%)$ & $20(29 \%)$ & $1(1 \%)$ & $4(6 \%)$ \\
\hline Total & & 100 & 44 & & 0 & 2 & 10 \\
\hline 10tal & & 100 & 34 & 34 & 20 & 2 & 10 \\
\hline \multicolumn{8}{|l|}{ Pre-IDDM } \\
\hline & $\leq 15$ & 10 & $3(30 \%)$ & $4(40 \%)$ & $2(20 \%)$ & $1(10 \%)$ & 0 \\
\hline & $>15$ & 17 & $7(41 \%)$ & $5(29 \%)$ & $1(6 \%)$ & $4(24 \%)$ & 0 \\
\hline Total & & 27 & $10(37 \%)$ & $9(33 \%)$ & $3(11 \%)$ & $5(19 \%)$ & 0 \\
\hline Control subjects & & 83 & $0(0 \%)$ & $1(1 \%)$ & $0(0 \%)$ & $0(0 \%)$ & $82(99 \%)$ \\
\hline
\end{tabular}

${ }^{\mathrm{a}} p<0.02$ vs $\leq 15$ years

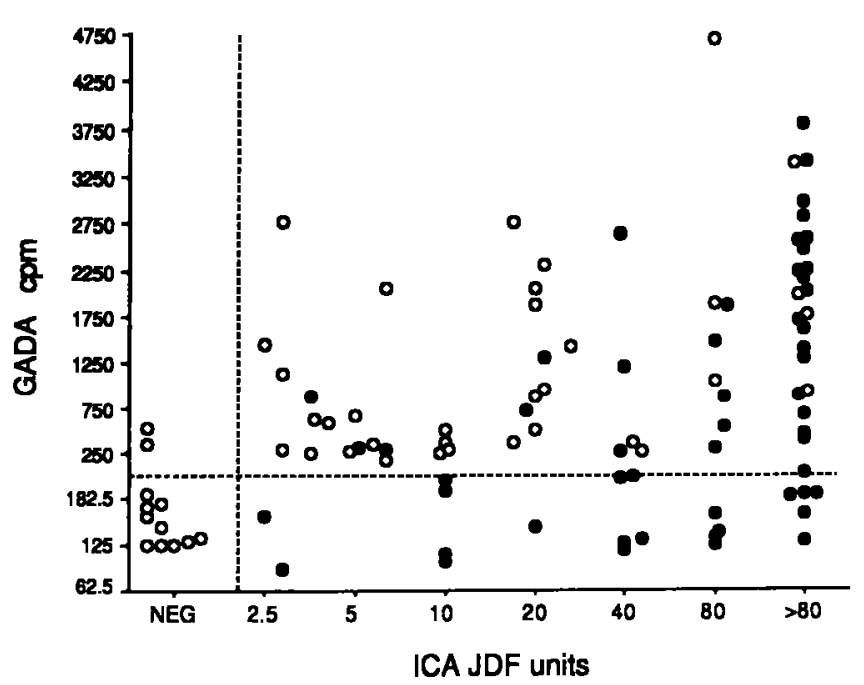

Fig. 3. Islet autoantibodies in sera from 100 newly-diagnosed IDDM patients. The filled symbols represent those in which anti-37 $\mathrm{K}$ were detected. The upper first percentile of $83 \mathrm{con}$ trol sera are represented by the broken lines at 2 JDF units for ICA and $217 \mathrm{cpm}$ for GADA

(CL: 80-94\%); 27 of these had between 2 and 19 JDF units and $61 \geq 20$ JDF units (Fig. 2A). ICA were the most frequently detected single humoral marker $\left(p<0.01\right.$ vs GADA; $p<10^{-6}$ vs anti-37 K) (Table 1$)$.
GADA were found in 70 IDDM patients (CL: 60$79 \%$ ) (Table 1; Fig.2B), including 2 of the 12 patients without detectable ICA. ICA in the absence of GADA were found in 20 patients, all of whom had an age of onset before age 15 years $(p<0.02$ vs $>15$ years) (Table 2 ). There was no correlation between GADA levels and ICA titres (Fig. 3).

Anti-37 K were found in 54 patients (CL: 44$64 \%)$; all had ICA ( $p<0.001$ vs ICA negative). They were detected more frequently in patients with disease onset before age 15 years $(p<0.05)$. Anti-37 K were strongly associated with high titre ICA and were detected in 35 of $42(81 \%)$ of those with ICA greater than $40 \mathrm{JDF}$ units $(p<0.002)$. All 20 cases with ICA in the absence of GADA had $37 \mathrm{~K}$ antibodies (Table 2). Anti-37 $\mathrm{K}$ were not associated with the presence of GADA (Fig. 3).

All sera were tested for antibodies to $\mathrm{CPH}$ and ICA69. None strongly immunoprecipitated in vitro translated CPH or ICA69. Thirteen had anti-CPH levels and four anti-ICA69 levels above the upper first percentile of normal control subjects (Fig.4).

ICA and/or GADA were detected in $90 \%$ of cases (CL: 82-95\%). The same cases could also be identified by the presence of GADA and/or anti-37 K. Four $(6 \%)$ patients with onset before age 15 years and $6(19 \%)$ patients with onset after age 15 years 


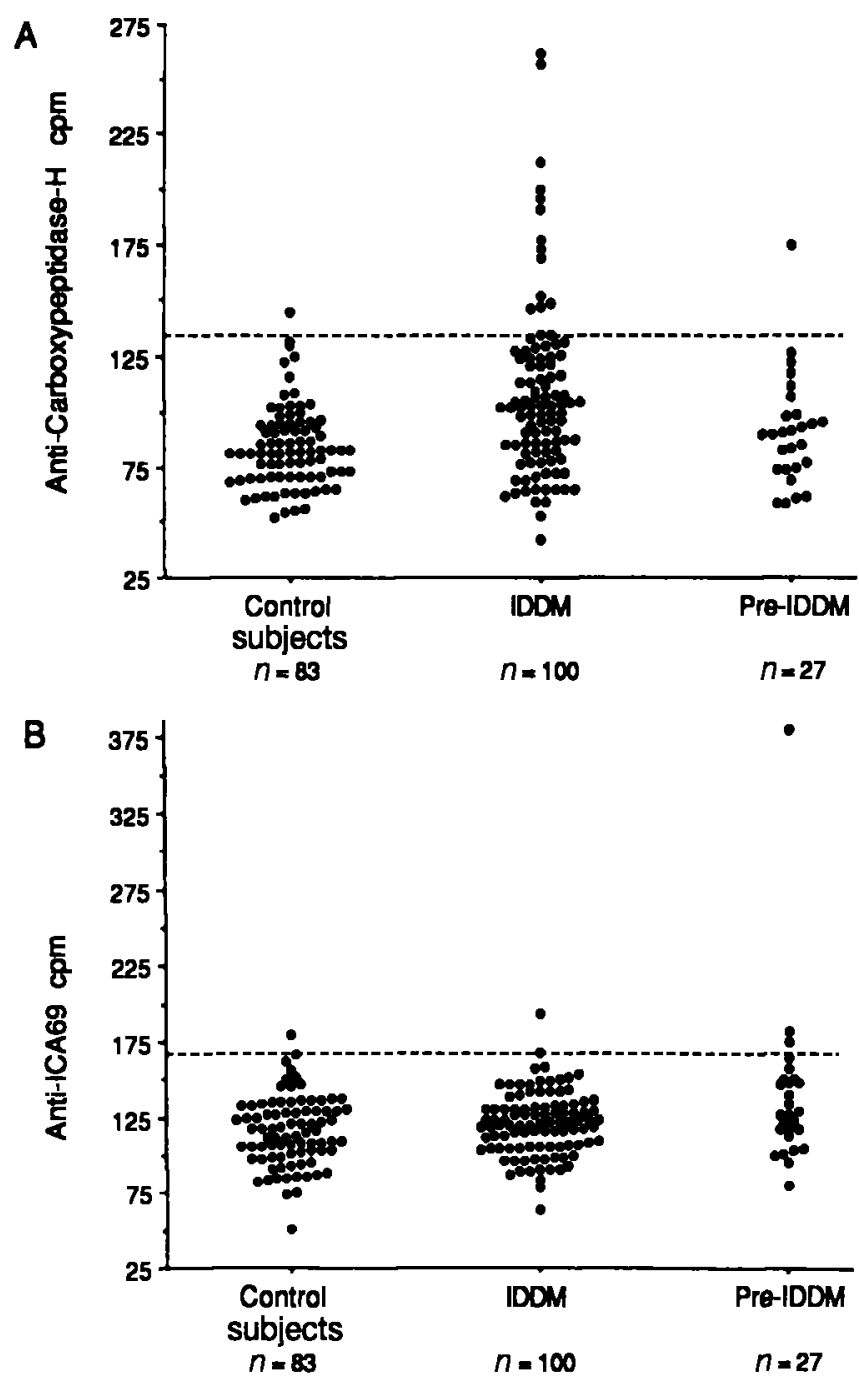

Fig.4 (A, B). Immunoprecipitation of in vitro translated (A) CPH and (B) ICA69. The upper first percentile of control subjects is shown by the broken lines

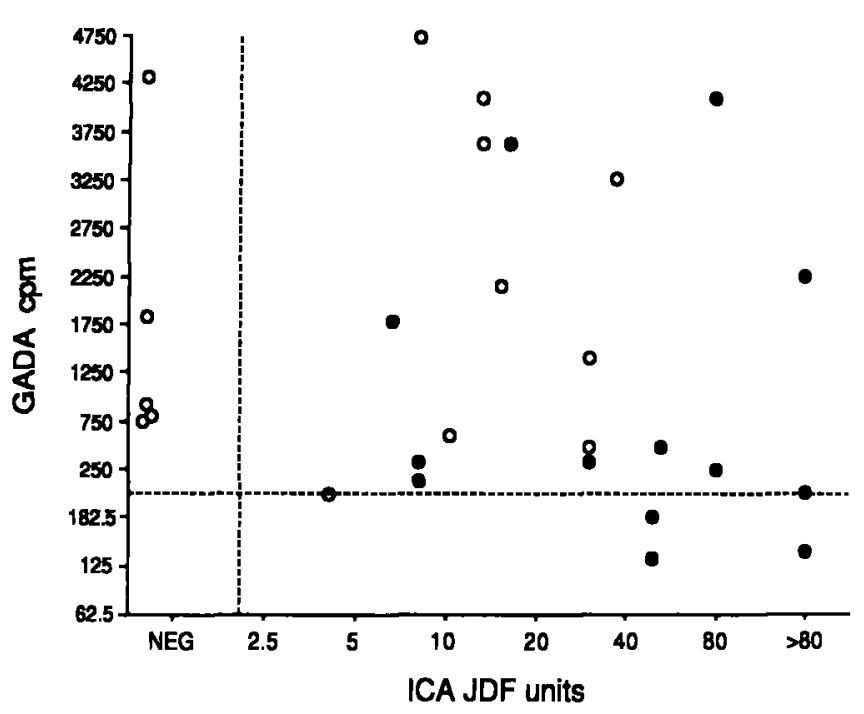

Fig. 5. Islet autoantibodies in sera from 27 pre-IDDM individuals. The filled symbols represent those in which anti-37 $\mathrm{K}$ were detected. The upper first percentile of 83 control sera are represented by the broken lines at 2 JDF units for ICA and $217 \mathrm{cpm}$ for GADA were negative for all three markers (Table 2). One of the antibody negative cases had IAA; none had increased levels of anti-ICA69 or anti-CPH.

Pre-IDDM. ICA and GADA were the most frequently detected single markers prior to onset of IDDM (Table 1; Fig. 5). Together they identified all 27 cases (CL: $87-100 \%)$. Five (19\%) had GADA in the absence of ICA and three (11\%) had ICA in the absence of GADA. Anti-37 K were found in 13 cases (48\%; CL: 29-68\%), all of whom also had ICA. These included all three cases with ICA in the absence of GADA (Table 2). One (4\%) had increased levels of anti-CPH, and three (11\%) had anti-ICA69 levels above the upper first percentile of normal control subjects (Fig. 4). No significant differences between pre-IDDM and IDDM at onset were found.

\section{Discussion}

Our aim was to develop a screening method based on islet autoantibody markers that will potentially identify most future cases of IDDM. The most sensitive markers were ICA and GADA. Both were detected in $68 \%$ of IDDM and $70 \%$ of pre-IDDM sera, and $90 \%$ of all IDDM and pre-IDDM sera had at least one of these markers. The majority of IDDM cases in which neither ICA nor GADA were detected were adult so that $94 \%$ of cases with onset before age 15 had at least one of these markers as against $81 \%$ over that age. Despite the high sensitivity of a combination of ICA and GADA, a significant proportion of patients had only one of these markers. In particular, $28 \%$ of those with childhood-onset disease had ICA without GADA.

Anti-37 $\mathrm{K}$ were the next most prevalent marker in newly-diagnosed IDDM. They were found only in conjunction with ICA, and strikingly, in all cases with ICA in the absence of GADA. Here again, $90 \%$ of IDDM cases, including $95 \%$ of those with onset before age 15 , and all pre-IDDM sera had either GADA or anti-37 K. ICA69 and CPH antibodies measured by immunoprecipitation were not detected in any of the GADA/anti-37 $\mathrm{K}$ negative cases, and did not increase sensitivity. IAA identified only one of these cases.

These findings suggest that ICA are the most sensitive screening test, particularly in childhood-onset diabetes, provided an assay is used that can detect low levels of antibody reproducibly. Even so, the assay is difficult to standardize, and many laboratories are unable to measure low levels consistently $[7,9]$. ICA contain more than one specificity [26-29], not all of which appear to be associated with IDDM [27]. Furthermore, ICA in the absence of other islet antibody specificities are only weakly predictive of IDDM in first-degree relatives [13] or schoolchildren 
[14]. In both groups increased risk is concentrated in the minority in whom more than one islet autoantibody specificity is present. In the present study, ICA were always found in association with either GADA or anti-37 K in sera taken both at and prior to diagnosis. It may therefore be preferable to undertake initial screening with those antibody specificities associated with ICA that are more closely related to disease.

GADA measurement has been proposed as a test to assess IDDM risk [12]. The assay output is numerical, removing some observer bias, and since many samples with low ICA levels have GADA levels well above the threshold for positivity used in this study, their use would avoid the difficulty of measuring low titre ICA. GADA appear to be as sensitive as ICA in adult-onset IDDM, but we found that $28 \%$ of patients diagnosed before age 15 years have ICA in the absence of GADA at or before disease onset. This group is of particular importance in that every case had anti-37 K, a marker associated with rapid progression to insulin-requiring diabetes $[13,14,30]$, thus implying an aggressive disease process. GADA measurement alone is therefore unlikely to provide as sensitive a screening test as ICA.

Our findings suggest that measuring GADA and anti-37 $\mathrm{K}$ could provide a test that would retain the sensitivity of ICA. Combining anti-37 $\mathrm{K}$ and GADA significantly enhances the sensitivity of GADA alone, and the combination of anti-37 $\mathrm{K}$ and ICA identifies a subgroup with markedly increased risk $[13,14,30]$. Current methods for anti-37 $\mathrm{K}$ are laborious and costly, and preclude the general application of this marker. Anti-37 K are however, like GADA, detected by immunoprecipitation of liquid phase antigen using small serum volumes. Therefore, provided the $37 \mathrm{k}$ antigen is cloned, it is likely that assays can be developed which will measure antibodies to in vitro translated recombinant GAD and $37 \mathrm{~K}$ antigen simultaneously. Additions of ICA69 or CPH antibodies contributed little to the analysis. Antibodies to ICA69 which have been detected in solid-phase assays $[20,24]$ rarely immunoprecipitate in vitro translated antigen [24], and increased binding to $\mathrm{CPH}$ was detected in only few sera and was not confined to GADA negative cases. IAA were not tested in all cases used in the present analysis, but we have previously found them to be absent prior to disease onset in a number of those with anti-37 $\mathrm{K}$ in the absence of GADA [13, 14]. Furthermore, the large serum volumes currently needed for the detection of IAA render these unsuitable for adaptation to screening assays for use in the general population.

In conclusion, we propose that a combination of GADA and anti-37 $\mathrm{K}$ testing could eventually replace ICA in screening for risk of IDDM. Until assays with the capacity to measure anti-37 $\mathrm{K}$ in large numbers of samples are available, we suggest that maximum sensitivity will be achieved by a combina- tion of GADA and ICA. The screening strategies we propose have the potential to identify more than $90 \%$ of future cases. We have tested this prospectively only in first degree relatives of children with IDDM in the UK, but the combinations of antibodies seen in these individuals are not different to those in the Italian non-familial cases at diagnosis, or to the few cases identified in a prospectively followed UK population of school children [14]. It is important to emphasise that the aim of the present analysis is to identify an approach to screening that maximizes sensitivity, thus identifying the greatest possible number of individuals at risk of developing IDDM within the general population. Additional or sequential tests, for example genetic analysis or metabolic testing, may then need to be applied to those with antibody markers in order to improve the specificity of prediction [31]. This approach promises in time to identify levels of risk sufficient to justify intervention trials in those with no family history of IDDM.

Acknowledgements. The authors wish to thank: Dr. C. Socci for providing purified human islets; Dr. N. Dozio for IAA measurements; Dr. M. Christie for providing the RIN 5AH cell line and for assistance in establishing the anti-37 $\mathrm{K}$ assay in Milan; Dr. J. Hutton and Dr. P. Guest for providing the rat $\mathrm{CPH}$ cDNA clone and anti-CPH antiserum; and Professor G. Pozza for support. The Barts-Windsor and Barts-Oxford family studies were supported by the British Diabetic Association.

\section{References}

1. Skyler JS, Marks JB (1993) Immune intervention in type 1 diabetes mellitus. Diabetes Rev 1: 15-42

2. Bonifacio E, Bingley PG, Shattock M et al. (1990) Quantification of islet cell antibodies and prediction of insulin-dependent diabetes. Lancet 335: 147-149

3. Riley WJ, Maclaren NK, Krischer J et al. (1990) A prospective study of the development of diabetes in relatives of patients with insulin-dependent diabetes. N Engl J Med 323: 1167-1172

4. Knip M, Vahasalo P, Karjalainen J, Lounamaa R, Akerblom HK, and the Childhood Diabetes in Finland Study group (1994) Natural history of preclinical IDDM in high risk siblings. Diabetologia 37: 388-393

5. Bottazzo GF, Florin-Christensen A, Doniach D (1974) Islet cell antibodies in diabetes mellitus with autoimmune polyendocrine deficiency. Lancet ii:1279-1283

6. Gleichmann H, Bottazzo GF (1987) Progress towards standardization of cytoplasmic islet cell antibody assays. Diabetes $36: 578-584$

7. Bonifacio E, Lernmark A, Dawkins RL et al. (1988) Serum exchange and use of dilutions have improved precision of measurement of islet cell antibodies. J Immunol Methods 106: 83-88

8. Bonifacio E, Boitard C, Gleichmann H, Shattock MA, Molenaar JL, Bottazzo GF (1990) Assessment of precision, concordance, specificity and sensitivity of islet cell antibody measurement in 41 assays. Diabetologia 33: 731736

9. Greenbaum CJ, Palmer JP, Nagataki S et al. (1992) Improved specificity of ICA assays in the Fourth Internation- 
al Immunology of Diabetes serum exchange Workshop. Diabetes 41: 1570-1574

10. De Aizpurua HJ, Harrison LC, Cram DS (1992) An ELISA for antibodies to recombinant glutamic acid decarboxylase in IDDM. Diabetes 41: 1182-1187

11. Thivolet CH, Tappaz M, Durand A et al. (1992) Glutamic acid decarboxylase (GAD) autoantibodies are additional predictive markers of type I (insulin-dependent) diabetes mellitus in high risk individuals. Diabetologia 35: 570-576

12. Tuomilehto J, Zimmet P, Mackay IR et al. (1994) Antibodies to glutamic acid decarboxylase as predictiors of insulin-dependent diabetes mellitus before clinical onset of disease. Lancet 343: 1383-1385

13. Bingley PJ, Christie MR, Bonifacio E et al. (1994) Combined analysis of autoantibodies improves prediction of IDDM in islet cell antibody positive relatives. Diabetes 43 : 1304-1310

14. Genovese S, Bingley PJ, Bonifacio E et al. (1994) Combined analysis of IDDM-related autoantibodies in healthy schoolchildren. Lancet 344: 756

15. Grubin CE, Daniels T, Toivola B et al. (1994) A novel radiobinding assay to determine diagnostic accuracy of isoform-specific glutamic acid decarboxylase antibodies in childhood IDDM. Diabetologia 37: 344-350

16. Petersen JS, Hejnaes KR, Moody A et al. (1994) Detection of $\mathrm{GAD}_{65}$ antibodies in diabetes and other autoimmune diseases using a simple radioligand assay. Diabetes 43: 459-467

17. Bosi E, Bonifacio E (1994) Autoantibodies in insulindependent diabetes mellitus. J Endocrinol Invest 17: 521531

18. Christie MR, Vohra G, Champagne P, Daneman D, Delovitch TL (1990) Distinct antibody specificities to a 64-kD islet cell antigen in type 1 diabetes as revealed by trypsin treatment. J Exp Med 172: 789-795

19. Castano L, Russo E, Zhou L, Lipes MA, Eisenbarth GS (1991) Identification and cloning of a granule autoantigen (carboxypeptidase- $\mathrm{H}$ ) associated with type 1 diabetes. J Clin Endocrinol Metab 73: 1197-1201

20. Pietropaolo M, Castano L, Babu S et al. (1993) Islet cell autoantigen $69 \mathrm{kD}$ (ICA69). Molecular cloning and characterization of a novel diabetes-associated autoantigen. J Clin Invest 92: 359-371
21. Hornes E, Jacobsen KS, Gabrielsen OS, Kornses LS, Jansen EB, Eselund M (1991) Purification of mRNA and DNA binding proteins using magnetic beads. In: Kemshead JT (ed) Magnetic separation techniques applied to cellular and molecular biology. Wordsmith Conference Publications. Somerset, UK, pp 197-205

22. Wang AM, Doyle MV, Mark FF (1989) Quantitation of mRNA by the polymerase chain reaction. Proc Natl Acad Sci USA 86: 9717-9721

23. Saiki, RK, Gelfand DH, Stoffel S et al. (1988) Primerdirected enzymatic amplification of DNA with a thermostable DNA polymerase. Science 239: 487-491

24. Lampasona V, Ferrari M, Bosi E, Pastore RM, Bingley PJ, Bonifacio E (1994) Sera from patients with IDDM and healthy individuals have antibodies to ICA69 on Western blots but do not immunoprecipitate liquid phase antigen. J Autoimmun 7: 665-674

25. Levi-Marchal C, Bridel M-P, Sodoyez-Goffaux F et al. (1991) Superiority of radiobinding assay over ELISA for detection of IAAs in newly diagnosed type 1 diabetic children. Diabetes Care 14: 61-63

26. Genovese S, Bonifacio E, McNally JM et al. (1992) Distinct cytoplasmic islet cell antibodies with different risks for type 1 (insulin-dependent) diabetes mellitus. Diabetologia 35: 385-388

27. Gianani R, Pugliese A, Bonner-Weir S et al. (1992) Prognostically significant heterogeneity of cytoplasmic islet cell antibodies in relatives of patients with type I diabetes. Diabetes 41 : $347-353$

28. Timsit J, Caillat-Zucman S, Blondel H, Chédin P, Bach JF, Boitard C (1992) Islet cell antibody heterogeneity among type 1 (insulin-dependent) diabetic patients. Diabetologia 35: 792-795

29. Atkinson MA, Kaufman DL, Newman D, Tobin AJ, Maclaren NK (1993) Islet cell cytoplasmic autoantibody reactivity to glutamate decarboxylase in insulin-dependent diabetes. J Clin Invest 91: 350-356

30. Christie MR, Genovese S, Cassidy D et al. (1994) Antibodies to islet $37 \mathrm{k}$ antigen, but not to glutamate decarboxylase, discriminate rapid progression to IDDM in endocrine autoimmunity. Diabetes 43: 1254-1259

31. Bingley PJ, Bonifacio E, Gale EAM (1993) Can we really predict IDDM? Diabetes 42: 213-220 